\title{
ENERGETIC PERFORMANCE ASSESSMENT OF A THERMO-SOLAR GREENHOUSE FISH (NILE TILAPIA) HATCHERY
}

\author{
Mona M. Kassem ${ }^{1}$, Atef M. Elsbaay ${ }^{2}$, Said E. AbouZaher ${ }^{2}$ and \\ Ismail A. Abdelmotaleb ${ }^{3}$
}

\begin{abstract}
Energetic performance of a thermo-solar greenhouse representing a fish hatchery system was suggested, developed and investigated. The developed system was mainly consisted of a double cover greenhouse coupled with solar collector and heat exchanger for water heating. The main aim was to control the water environment, namely temperature and dissolved oxygen, of a fish (Nile Tilapia) hatchery at the desired levels. The main experimental work was carried out during the period from December 2014 to February 2015. The suggested and investigated system based mainly on solar energy as the source of power. However, an auxiliary heating system, namely an electric heater was used upon request. The experimental system was constructed and investigated at the research farm, Faculty of Agriculture, Kafrelsheikh University $\left(31.07^{\circ} \mathrm{N}\right.$ and $30.57^{\circ}$ E) Kafrelsheikh governorate, Egypt. Environmental parameters; namely temperature, solar radiation, relative humidity, wind speed and water quality in terms of dissolved oxygen were monitored. The results indicated an efficient control in water temperature and quality. The average temperature and dissolved oxygen concentration of fish pond water throughout the whole experimental period were $26.8(S D=0.15)$ ${ }^{\circ} \mathrm{C}$ and 7.62 (SD =0.68) ppm respectively. The average value of air temperature rise inside the greenhouse was $8.4^{\circ} \mathrm{C}$. The average value of total daily water energy gained via the heat exchanger system was 18.185 $M J /$ day per $m^{2}$ of the fish pond water surface area at an average value of $13.433 \mathrm{MJ} /\left(\mathrm{m}^{2}\right.$.day) of the incident solar radiation on the horizontal plane. As a conclusion the weekly average percentage of energy
\end{abstract}

\footnotetext{
${ }^{1}$ Assistant Lecturer, Agric. Eng. Dept., Faculty of Agric., Kafrelsheikh Univ., Egypt. E-mail: ma7koko@yahoo.com

${ }^{2}$ Assistant Professor, Agric. Eng. Dept., Faculty of Agric., Kafrelsheikh Univ., Egypt,

${ }^{3}$ Professor, Agric. Eng., Dept., Faculty of Agric., Kafrelsheikh Univ., Egypt.
} 
contribution of both greenhouse action and heat exchanger operating times were 58.13 and $41.87 \%$ respectively as a percentage of the whole operating time.

Keywords: Greenhouse, Fish pond, Fish hatchery, Solar energy, Nile Tilapia.

\section{INTRODUCTION}

$\int$ gypt is the largest aquaculture producer in Africa and the $8^{\text {th }}$ largest globally. In 2011 the aquaculture production was about 986,820 tonnes (FAO, 2013). Nile tilapia is an economically important cultured species in several areas of the world (El-Saidy and Gaber, 2005 and El-Husseiny et al., 2007). In Egypt, the target area for producers was Kafrelsheikh Governorate, as this is the main fish producing area with about 324,479 tonnes $(55 \%$ of the national farmed fish production) and a total tilapia production of 259,583 tonnes (44\% of the national farmed tilapia production) .

Mapping of the fish seed value chain in early 2012 revealed that there has been a corresponding expansion of the tilapia hatchery sector. The Egyptian fish seed sector started in the 1980 when the government decided to establish 14 freshwater carp hatcheries (Saleh, 2007 and NasrAllah et al., 2012). These hatcheries also started spawning tilapia in earthen ponds using the methods described by Little and Hulata (2000). The first private tilapia hatchery started operation in 1992, increasing to seven by 1996 and reaching 135 licensed and an unknown number of unlicensed hatcheries by 2010 (Radwan, 2008 and GAFRD, 2011). Mapping by the Improving Employment and Incomes through Development of Egypt's Aquaculture Sector (IEIDEAS) project in 2012 mentioned that there are around 440 tilapia hatcheries in Egypt (NasrAllah et al., 2012).

A recent modification of hapa-based systems has been to cover ponds with greenhouses to increase water temperatures and facilitate early spawning of tilapia (Saleh, 2007). Other hatchery operators have developed tank based spawning systems, also enclosed by greenhouses and often supplied with heated water from boilers or groundwater (Sadek, 2011). Using these systems, hatchery operators are able to meet the high 
demand for seed by fish farmers early in the season (Abou-Zied and Ali, 2007; Saleh, 2007; Radwan, 2008; Eldokla et al., 2011; Naiel et al., 2011; Macfadyen et al., 2012 and Nasr-Allah et al., 2012;). Egyptian tilapia hatcheries operate on a seasonal basis as temperatures are too low during winter months (from November to February). The usual tilapia spawning cycle in Egypt starts with stocking of breeding systems with brood fish in February to April. Collection of fry starts two weeks after brood fish are stocked. Heated greenhouse hatcheries start stocking brooders and warming water in February, while hapa-based hatcheries start stocking brooders in April (Saleh, 2007 and Nasr-Allah et al., 2012).

Water temperature affects the feeding pattern and growth of fish. Fish generally experience stress and disease breakout when temperature is chronically near their maximum tolerance or fluctuates suddenly. Warm water holds less dissolved oxygen than cool water. Oxygen consumption is directly linked to size of fish, feeding rate, activity level and pond temperature. Low dissolved oxygen concentration is recognized as a major cause of stress, poor appetite, slow growth, disease susceptibility and mortality in aquaculture species (Mwegoha, et al. 2010). Dissolved oxygen is not only important for fish respiration, but also is important for the survival of phytoplankton, the organism which breaks down toxic ammonia into harmless forms.

According to Shaheen, (2013) the optimum water environmrnt for fish (Nile Tilapia) hatchery is illustrated in Table 1. spawn 4-6 times per year, 100-500 eggs per brood.

Table 1: The optimum water environmrnt for fish (Nile Tilapia) hatchery

\begin{tabular}{|l|l|}
\hline Element & Range \\
\hline Temperature & $22-30^{\circ} \mathrm{C}$ \\
\hline pH (related to water temp.) & $6.5-9.0$ \\
\hline Dissolved oxygen level $\left(\mathrm{O}_{2}\right)$ required & $>5 \mathrm{ppm}$ \\
\hline Total alkalinity & $10-100 \mathrm{mg} / \mathrm{L}$ \\
\hline Total hardness & $50-250 \mathrm{mg} / \mathrm{L}$ \\
\hline Free carbon dioxide & $2-12 \mathrm{mg} / \mathrm{L}$ \\
\hline
\end{tabular}

Fuller (2007) concluded from his simulation study under Australia (Melbourne and Mildura) conditions that in a hot dry climate, the greenhouse alone was sufficient to reduce the conventional energy 
requirements by $87 \%$; while in the cooler temperate climate reductions of $66 \%$ were possible. When solar collectors were added to the system, conventional energy requirements were reduced further and depended on the area of collector used. He added that in a hot sunny climate a double skin greenhouse alone can provide significant savings, when relatively small rises $\left(5-6^{\circ} \mathrm{C}\right)$ in water temperature are required.

The main aim of the present study was to control the water environment, namely temperature and dissolved oxygen, of a fish (Nile Tilapia) hatchery at the desired levels. A thermo-solar greenhouse representing a fish hatchery system was developed. And its energetic performance was emphasized and investigated.

\section{MATERIALS AND METHODS}

The main experimental work of the present study was carried out during the period from December 2014 to February 2015. The experimental system was developed and constructed at the research farm, Faculty of Agriculture, Kafrelsheikh University (31.07 ${ }^{\circ} N$ and $\left.30.57{ }^{\circ} \mathrm{E}\right)$ Kafrelsheikh governorate, Egypt. Air temperature, fish pond water temperature, relative humidity, solar radiation, wind speed and dissolvedoxygen were mainly measured. The main components of the developed system were greenhouse, fish pond, solar collector for water heating, thermal storage water tank and a heat exchanger. Fish pond water was supplied from an irrigation watercourse. Figure 1 illustrates the whole system and more details for each component are given below.

\section{System components:}

The greenhouse was designed as a trapezoid cross sectional shape and oriented east-west. The largest surface area which was the upper one was inclined at nearly $36^{\circ}$ with the horizontal and facing south (Figure $1 \mathrm{~A}$ and $\mathrm{B}$ ). The greenhouse covered by double layer polyethylene sheets of $60 \mu \mathrm{m}$ (inner layer) and $200 \mu \mathrm{m}$ (outer layer) having an air gap around 10 $\pm 2 \mathrm{~cm}$. The geometric characteristics of the greenhouse are shown in Table 2 .

The fish pond included two phases which are spawning and nursery. It was built from $25 \mathrm{~cm}$ thickness common bricks having internal dimensions of $4 \times 1 \times 1 \mathrm{~m}$ for length $\times$ width $\times$ depth respectively. 


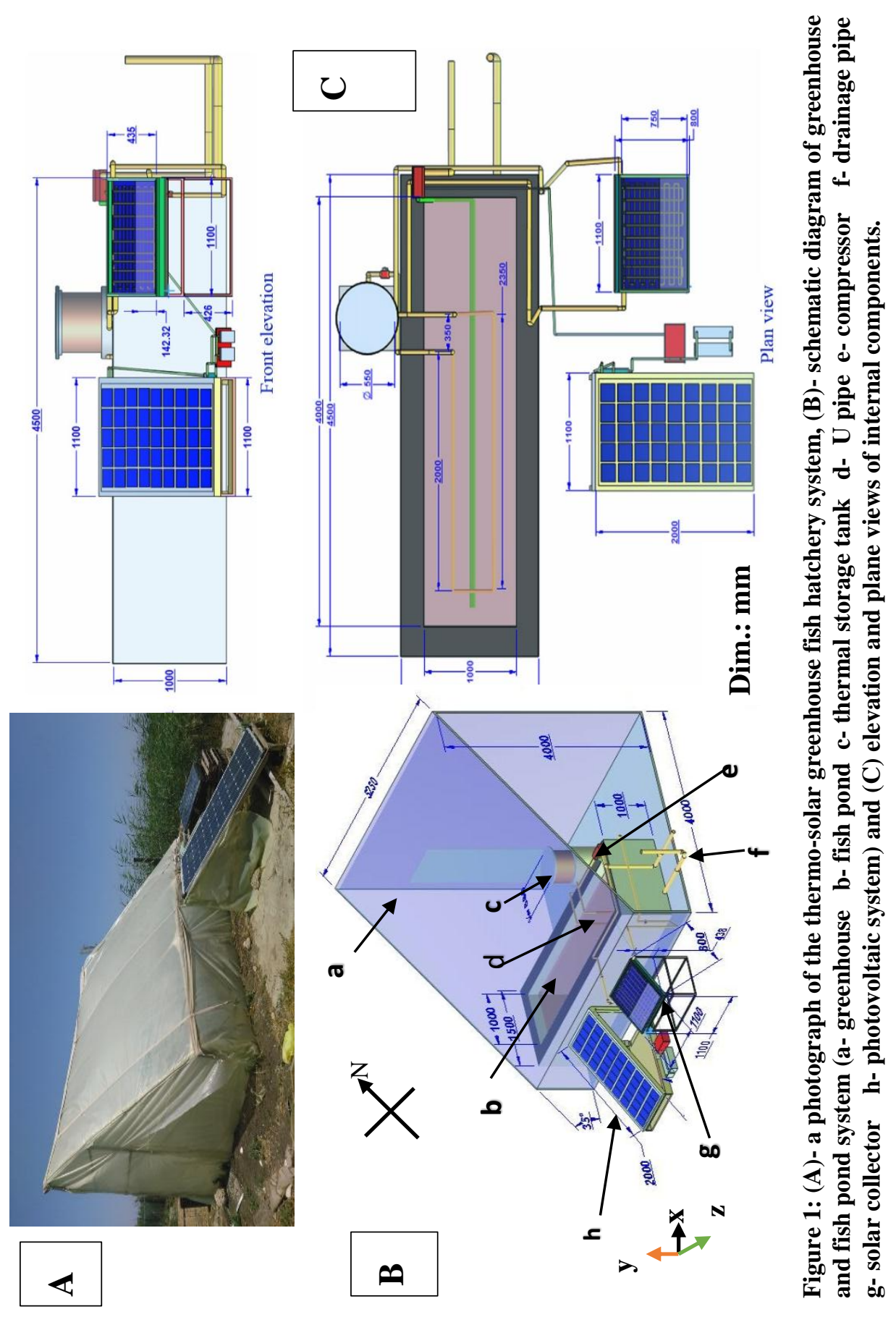


A drainage pipe at the pond bottom has a vertical extension of $75 \mathrm{~cm}$ was attached to manipulate water drain and to maintain a $75 \mathrm{~cm}$ water depth within the fish pond (Figure $1 \mathrm{~B}$ and $\mathrm{C}$ ). Water volume of $3 \mathrm{~m}^{3}$ was the main target environment to be controlled at a temperature of $27 \pm 1{ }^{\circ} \mathrm{C}$ by the aids of other components. An AC 100 Watt air compressor powered by a photovoltaic system and inverter for change DC electric to AC were used for aeration process. It blows $110 \mathrm{~L} / \mathrm{min}$ of air through a leaky pipe extended along the longitudinal axis of the fish pond floor. A thermocouple sensor (PT100) was placed at the center of the fish pond to detect water temperature.

Table 2. The geometric characteristics of the greenhouse:

\begin{tabular}{|l|c|c|}
\hline Member & External dimensions & Unit \\
\hline The largest height & 4.00 & $\mathrm{~m}$ \\
\hline The lowest height & 1.10 & $\mathrm{~m}$ \\
\hline The total length & 5.25 & $\mathrm{~m}$ \\
\hline The total width & 4.00 & $\mathrm{~m}$ \\
\hline The inclined edge & 4.94 & $\mathrm{~m}$ \\
\hline The total surface area & 73.12 & $\mathrm{~m}^{2}$ \\
\hline The total volume & 47.02 & $\mathrm{~m}^{3}$ \\
\hline
\end{tabular}

The solar collector for water heating was made from local materials, the outer frame was made of $4 \mathrm{~cm}$ thickness wood, having external dimensions of $110 \times 80 \times 15 \mathrm{~cm}$. The absorber of the solar collector was made of a matt black painted galvanized corrugated sheet. Net surface area of the absorber was $0.777 \mathrm{~m}^{2}$. A grid of matt black painted copper tubes have a total length of $19 \mathrm{~m}$ and $1.6 \mathrm{~cm}$ external diameter was fixed on the absorber for water pass. A 90 Watt water pump having $3.4 \mathrm{~L} / \mathrm{min}$ discharge was used to circulate the water from the storage tank to solar collector and vis versa in a closed circuit. This pump was controlled by a timer to be operated from 9:00 am to 3:00 pm.

A thermal storage water tank having a total volume of $225.8 \mathrm{~L}$ and contains about $150 \mathrm{~L}$ of water was used to store the solar heated water. It was thermally insulated by $2 \mathrm{~cm}$ thickness of glass wool and was kept inside the greenhouse. It was connected to both the solar collector and the heat exchanger each in a separate closed circuit via thermally insulated pipes. It was equipped with 1100 Watt electric heater that can be used 
upon request to maintain the water temperature within the tank around 40 $\pm 3{ }^{\circ} \mathrm{C}$ by using a thermostat.

A heat exchanger of a U-shaped copper pipe having $6.45 \mathrm{~m}$ total length and $1.6 \mathrm{~cm}$ external diameter was constructed and placed upon the floor of the fish pond. Another 90 Watt water pump having $3.4 \mathrm{~L} / \mathrm{min}$ discharge was used to circulate the water from the storage tank to the heat exchanger and vis versa in a closed circuit as well. This pump was controlled by another digital thermostat placed within the fish pond and adjusted at the targeted temperature of $27 \pm 1^{\circ} \mathrm{C}$.

\section{Instrumentation and Measurements:}

Table 3 shows the measuring devices, models and measured parameters. Figure 2 illustrates a schematic diagram for the measurement point locations for the whole system. Temperature, relative humidity and wind speed were detected and monitored on an hourly basis throughout the entire day for the greenhouse and the confined components. Solar radiation, light intensity and water dissolved oxygen were detected during the daytime hours on an hourly basis as well. However water electrical conductivity, $\mathrm{pH}$ and total ammonia were also checked.

\section{Experimental procedure:}

The whole experimental system was constructed, each component was checked and the water temperature and quality was set at the desired levels. The main experimental work started from 27/12/2014 to $11 / 2 / 2015$, where the male and female fishes were brought at a broodstock density ratio 1:3 male: female. Based on the recommended brood stocking density of 3 fishes per square meter of water pond surface in addition to about $33 \%$ extra to overcome regionalization and mortality, previously prepared 4 males and 12 females of fish were submerged within the fish pond. A photoperiod of about 14 hour/day was achieved by the aid of 36 Watt electric daylight power saving lamp. The experiment period extended to the end of the first month of age of the produced fingerlings. The traditional feeding process was applied. Water exchange at the rate of almost $5 \%$ of total water volume was applied daily to avoid ammonia accumulation. 
Table 3: Measuring devices, models and measured parameters.

\begin{tabular}{|l|l|l|l|}
\hline Device & Model & Measurement & Unit \\
\hline Data logger - 48 channel & UTX-48 channel & Temperature & ${ }^{\circ} \mathrm{C}$ \\
\hline Micro Data Logger Log Box-AA. & IP67 & Temperature & ${ }^{\circ} \mathrm{C}$ \\
\hline Dissolved oxygen meters. & 820 & Dissolved oxygen & $\mathrm{ppm}$ \\
\hline $\begin{array}{l}\text { KlimaLogg professional } \\
\text { thermohygrometer }\end{array}$ & $30.3039 . \mathrm{IT}$ & $\begin{array}{l}\text { Temperature and } \\
\text { relative humidity }\end{array}$ & $\begin{array}{c}{ }^{\circ} \mathrm{C} \text { and } \\
\%\end{array}$ \\
\hline Lux / Light meter & LX802 & Light intensity & $\mathrm{LUX}$ \\
\hline Anemometer & AM-4838 & Wind speed & $\mathrm{m} / \mathrm{s}$ \\
\hline Datalogging digital solar power meter & TES-1333R & Solar irradiance & $\mathrm{W} / \mathrm{m}^{2}$ \\
\hline pH meter & pH 510 & pH & \\
\hline Ammonia MR (medium range) & Mi405 & Total ammonia & $\mathrm{ppm}$ \\
\hline EC meter & K410 & Electrical Conductivity & $\mathrm{dS} / \mathrm{m}$ \\
\hline
\end{tabular}

\section{Parameters calculations:}

The following calculated parameters were determined and used to assess the energetic performance of the suggested thermo-solar greenhouse fish hatchery. All the following energetic parameters were detected at a steady state instant in Watts, then the corresponding energy streams throughout a specified period of hours time (intervals) and in turn for days in Joules were integrated. Consequently the total daily cumulative values and hourly and daily averages were calculated. Table 4 summarizes inputs and specification parameters used in the following calculations. Assumptions such as the system worked under steady-state conditions, neglecting of both thermal energy of the lamp and electrical energy consumed in water exchange process.

The following energetic performance assessment based mainly on the solar energy thermal analysis for the whole system. However, parameters to judge the environmental control level within the fish pond were presented. An indicator represents the contribution percentage as a function of actual operating time belongs to some system components, namely heat exchanger pump and greenhouse action operating times, in the required energy were calculated as well.

\section{Solar collector system:}

The following are thermal analysis of the solar collector related to the targeted energetic performance of the whole system. However, all the following parameters and equations are based on Duffie and Becman (2013). 


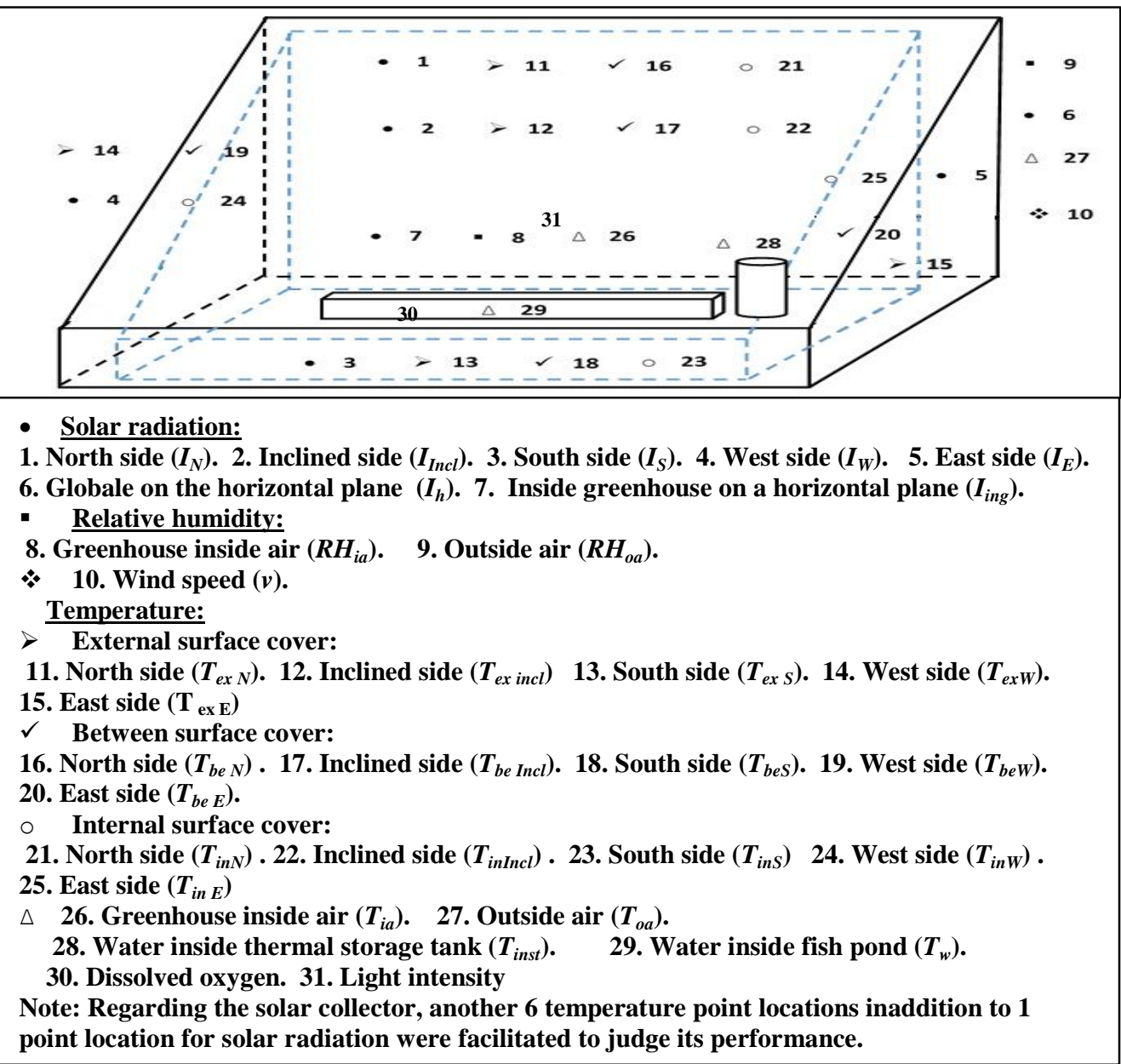

Figure 2: A schematic diagram for the measuring point locations.

- Available solar energy $(Q)$ :

The available solar energy $(Q)$ in Watts was computed as:

$Q=I_{\text {coll }} \boldsymbol{A}_{\text {coll }}$

Where:

$I_{\text {coll: }}$ : solar irradiance incident on the surface of the solar collector, $\mathrm{W} / \mathrm{m}^{2}$ $A_{\text {coll }}$ : Net surface area of the of the absorber plate, $\mathrm{m}^{2}$

- Absorbed solar energy $\left(Q_{a}\right)$ :

The absorbed solar energy $\left(Q_{a}\right)$ in Watts can be calculated as a function of an assumed average value of transmittance-absorptance product $(\tau \alpha)$ as follows:

$Q_{a}=Q(\tau \alpha)$ 
Where:

$\tau$ : Effective transmittance of glass cover, decimal

$\alpha$ : Effective absorptance of the absorber, decimal

Table 4: Inputs and specification parameters used to assess the energetic performance of the suggested thermo-solar greenhouse fish hatchery.

\begin{tabular}{|l|l|c|}
\hline Inputs and specification parameter & Value & Unit \\
\hline Specific heat of water, $\left(\boldsymbol{C}_{\boldsymbol{w}}\right)$ & 4186 & $\mathrm{~J} /(\mathrm{kg} . \mathrm{K})$ \\
\hline $\begin{array}{l}\text { Water mass flow rate (for solar collector and } \\
\text { heat exchanger), } \boldsymbol{m})\end{array}$ & 3.4 & $\mathrm{~kg} / \mathrm{min}$ \\
\hline solar collector: & & \\
\hline $\begin{array}{l}\text { Net surface area of the absorber of the solar } \\
\text { collector, }\left(\boldsymbol{A}_{\text {coll }}\right)\end{array}$ & $(0.74 \times 1.05)=0.777$ & $\mathrm{~m}^{2}$ \\
\hline Effective absorptance of the absorber $(\boldsymbol{\alpha})$ & 0.89 & decimal \\
\hline Effective transmittance of the glass cover $(\boldsymbol{\tau})$ & 0.96 & decimal \\
\hline (Greenhouse fish pond system: & & $\mathrm{m}^{2}$ \\
\hline Area of the vertical side facing north & $(4 \times 5.25)=21$ & $\mathrm{~m}^{2}$ \\
\hline Area of the inclined side facing south & $(4.94 \times 5.25)=25.94$ & $\mathrm{~m}^{2}$ \\
\hline Area of the vertical side facing south & $(1.1 \times 5.25)=5.775$ & $\mathrm{~m}^{2}$ \\
\hline Area of the vertical side facing west & $(1.1+4) / 2) \times 4=10.2$ & $\mathrm{~m}^{2}$ \\
\hline Area of vertical side facing east & $(1.1+4) / 2) \times 4=10.2$ & $\mathrm{decimal}^{2}$ \\
\hline Transmissivity of a single layer cover, $\left(\boldsymbol{\tau}_{\boldsymbol{s c}}\right)$ & 0.8 & \\
\hline
\end{tabular}

- Useful thermal energy gain to storage $\left(Q_{u}\right)$ :

Useful thermal energy gain to storage $\left(\boldsymbol{Q}_{u}\right)$ in Watts in terms of the sensible heat gained by the water through the solar collector was calculated as follows:

$Q_{u}=m C_{w}\left(T_{w o}-T_{w i}\right)$

Where:

$\mathrm{m}$ : Solar collector water mass flow rate, $\mathrm{kg} / \mathrm{s}$

$C_{w}:$ Specific heat of water, $\mathrm{J} /(\mathrm{kg} . \mathrm{K})$

$T_{w o}$ and $T_{w i}$ : water temperature at outlet and inlet respectively, ${ }^{\circ} \mathrm{C}$

For convenience, it should be mentioned here that throughout the operating period of 6 hours daily (time intervals) there were some times in which water returned to the solar collector at a temperature $\left(T_{w i}\right)$ higher than it would be exit $\left(T_{w o}\right)$. Therefore these times were excluded in $\boldsymbol{Q}_{u}$ calculation throughout the entire operating period. This phenomenon was accompanied with the overall thermal efficiency as well. 


\section{- Overall thermal efficiency $(\eta)$ :}

The overall thermal efficiency $(\eta)$ was calculated as follows:

$\boldsymbol{\eta}=\frac{\boldsymbol{Q}_{u}}{\boldsymbol{Q}} \times 100, \%$

\section{Greenhouse fish pond system:}

The energetic parameters such as solar energy transmitted and acquired through greenhouse covers, thermal load leveling, energy supplied to fish pond water by means of the heat exchanger were calculated. A suggested parameter based on operating time period to distinguish between the energy contribution of both heat exchanger and greenhouse action operating times was also caculated.

- Solar energy transmitted and acquired $\left(Q_{g h}\right)$ :

An Equation used by $\boldsymbol{L i}$ et $\boldsymbol{a l}$. (2009) for water was modified by eleminating the water optical parameter in the following form to be used to calculate $\boldsymbol{Q}_{g h}$ in Watts through each greenhouse side as follows: $Q_{g h}=\tau_{s c}^{2} A I$,

Where:

$\tau_{s c}$ : Transmissivity of a single layer cover to solar radiation, decimal $A$ : Surface area of the greenhouse side, $\mathrm{m}^{2}$

$I$ : Solar irradiance incident on the surface of greenhouse side, $\mathrm{W} / \mathrm{m}^{2}$

- Water energy gained from the heat exchanger $\left(Q_{w g}\right)$ :

Fish pond water energy gained from the heat exchanger $\left(\boldsymbol{Q}_{\boldsymbol{w g}}\right)$ was expressed as the sensible heat lost by pumping water through the heat exchanger pipe to be gained by the fish pond water. The temporal stored heat in the setelled water and pipe material were ignored. Therefore, $\boldsymbol{Q}_{w g}$ was calculated in Watts as follows:

$Q_{w g}=m C_{w}\left(T_{h e x i}-T_{\text {hexo }}\right)$,

Where:

$m$ : Heat exchanger water mass flow rate, $\mathrm{kg} / \mathrm{sec}$

$C_{w}:$ Specific heat of water, $\mathrm{J} /(\mathrm{kg} . \mathrm{K})$

$T_{\text {hexi }}$ : Water temperature measured inside the thermal storage tank and it was assumed to be the same as it would be at the point at which the heat exchanger pipe enters the fish pond since it was well insulated before that point, ${ }^{\circ} \mathrm{C}$

$T_{\text {hexo }}$ : Water temperature inside the heat exchanger pipe measured at the point at which the heat exchanger pipe leavs the fish pond, ${ }^{\circ} \mathrm{C}$ 
The $\boldsymbol{Q}_{w g}$ was integrated and calculated according to the recorded daily operating times of the heat exchanger pump in Jouls per day. Then it was specifed per $\mathrm{m}^{2}$ of the fish pond water surface area.

Daily operation time of the electric heater throughout the whole experimental period was recorded and used to calculate the traditional electrical energy in kW.h per day. Then it was specifed per $\mathrm{m}^{2}$ of the fish pond water surface area as well.

\section{Computation of thermal load leveling (TLL):}

Thermal load leveling (TLL) suggested by Jain and Tiwari (2003) gives an idea about the temperature fluctuation of water in the fish pond . It was calculated for each day as follows:

$$
T L L=\frac{T_{w \max }-T_{w \min }}{T_{w \max }+T_{w \min }}
$$

Where $T_{\text {wmax }}$ and $T_{\text {wmin }}$ are the maximum and minimum temperatures of water in the fish pond for each day. However, average and standard deviation (SD) of the fish pond water temperature thrgoughout the whole experimental period were indicated as well.

- Percentage of energy contribution of both heat exchanger and greenhouse action operating times:

The contribution percentage as a function of actual operating time belongs to both heat exchanger pump and greenhouse action in the heating requirements was calculated. Daily operation time of the heat exchanger pump ( $\left.\boldsymbol{t}_{\text {hexp }}\right)$ throughout the whole experimental time was recorded and used to calculate the daily percentage of energy contribution, as a fraction of time, of the heat exchanger $\left(t_{h e x}\right)$ as follows:

$$
t_{\text {hex }}=\frac{t_{\text {hexp }}}{24} \times 100, \%
$$

Therefore the daily percentage of energy contribution, as a fraction of time, of the greenhouse action $\left(t_{g h}\right)$ is the remaining portion of the day. Finally, the weekly average of both $t_{h e x}$ and $t_{g h}$ was then calculated.

\section{Fingerlings production rate:}

By the end of the fish hatchery season fingerlings was harvested by the traditional methods to get the approximate count. Then the production ratio was estimated as an average for each female of fish. 


\section{RESULTS AND DISCUSSION}

\section{Solar collector:}

Average values throughout the whole experimental period of outside air temperature $\left(T_{o a}\right)$, solar irradiance on the solar collector surface $\left(I_{c o l l}\right)$ and global solar irradiance on a horizontal plane $\left(I_{h}\right)$ were $15.27^{\circ} \mathrm{C}, 722 \mathrm{w} / \mathrm{m}^{2}$ and $475 \mathrm{w} / \mathrm{m}^{2}$, respectively. Figure 3 illustrates the values of hourly average solar irradiance incident on the solar collector surface $\left(\mathrm{I}_{\mathrm{coll}}\right)$, on a horizontal plane $\left(I_{h}\right)$, outside air temperature $\left(T_{o a}\right)$, inlet $\left(T_{w i}\right)$ and outlet $\left(T_{w o}\right)$ water temperature. As it was expected the outside air temperature increased with increasing the intensity of the solar radiation. In addition the incident solar radiation on the solar collector surface was higher than that on the horizontal. The largest values of the recorded solar irradiance on the solar collector surface, on the horizontal and outside air temperature were $890 \mathrm{w} / \mathrm{m}^{2}, 610.3 \mathrm{w} / \mathrm{m}^{2}$ and $17.75{ }^{\circ} \mathrm{C}$, respectively. In general it is clear that the hourly average water temperature rise did not exceed than $1.05{ }^{\circ} \mathrm{C}$ during the opearting period of the solar collector. This was due to the fact that the inlet water temperature represents the water temperature inside the thermal storage tank which was controled to be not less than approximately $40{ }^{\circ} \mathrm{C}$ by the aid of the electric heater. The desired action of the solar collector arises from hour 10 to hour 14 since water temperature increased from 42.5 to 47.3 and from 42.6 to $48.4{ }^{\circ} \mathrm{C}$ for the inlet and outlet respectively. However, it should be mentioned that the followed managing procedure of the solar collector led to some heat loss at the begining and at the ending of the solar collector operation. Accordingly, it was concluded as a recommenation that the managing procedure of the solar collector should be modified in a way to avoide heat loss and enhance its performance.

Figure 4 ( $\mathrm{a}$ and $\mathrm{b}$ ) shows the total daily of available solar energy $(Q)$, absorbed solar energy $\left(Q_{a}\right)$, useful thermal energy gain to storage $\left(Q_{u}\right)$ and overall thermal efficiency $(\eta)$ during the experimental period. Regarding $Q_{u}$ and in turn $\eta$ there were four days that can be classified as the coldest days $(5,7,8,9$ January 2015) having negative values and were excluded from the Figure. On the other hand there were some not recorded and missed data related to some other days were totally not shown on the Figure as well. 


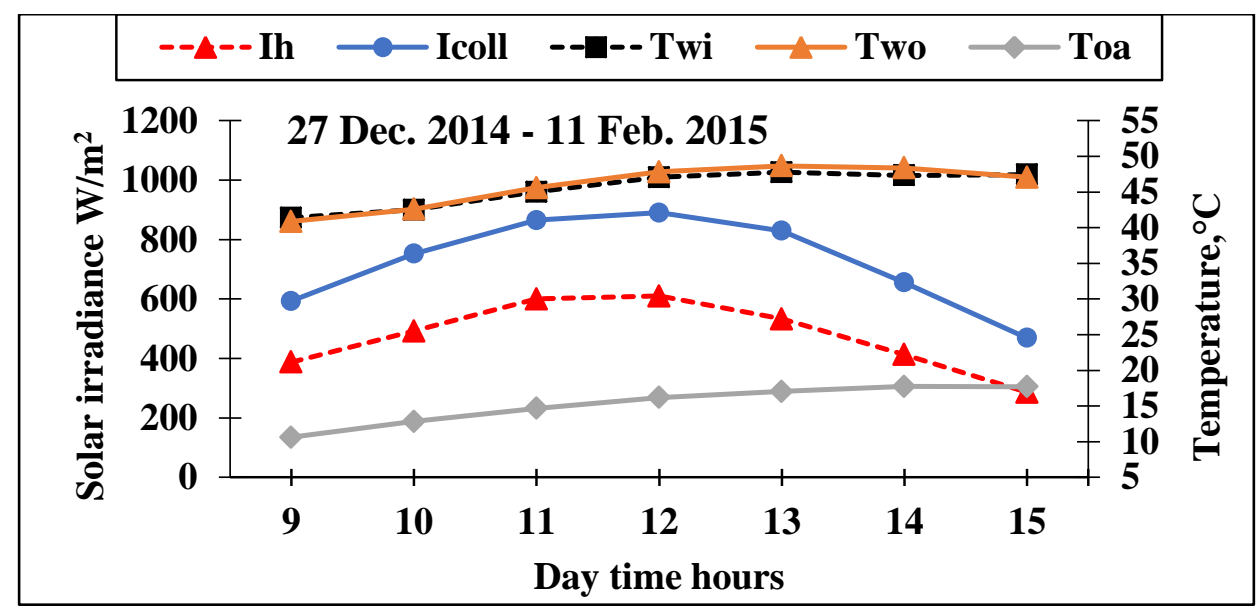

Figure 3: Hourly average solar irradiance incident on the solar collector surface $\left(I_{\text {coll }}\right)$, on a horizontal plane $\left(I_{h}\right)$, outside air temperature $\left(T_{o a}\right)$, inlet $\left(T_{w i}\right)$ and outlet $\left(T_{w o}\right)$ water temperature.

The largest values of $Q, Q_{a}, Q_{u}$ and $\eta$ during the experimental period were $18 \mathrm{MJ} /$ day, $16 \mathrm{MJ} /$ day, $12 \mathrm{MJ} /$ day and $67 \%$ respectively. However the average values throughout the experimental period were $13 \mathrm{MJ} / \mathrm{day}, 11$ $\mathrm{MJ} /$ day, $5 \mathrm{MJ} /$ day and 40\%, respectively.

\section{Greenhouse fish pond system:}

Figure 5 indicates related energetic parameters as outside ambient air temperature $\left(T_{o a}\right)$ and relative humidity $\left(R H_{o a}\right)$, inside air temperature $\left(T_{i a}\right)$ and relative humidity $\left(R H_{i a}\right)$, fish pond water temperature $\left(T_{w}\right)$ and wind speed for tow days representing a cold and moderate winter ones (Figure 5 (a) and (b) respectively). Hourly average values throughout the entire experimental period were indicated in Figure 5 (c). Grand mean for $T_{o a}, R H_{o a}, T_{i a}$ and $R H_{i a}$ were $13{ }^{\circ} \mathrm{C}, 74 \%, 21.4{ }^{\circ} \mathrm{C}$ and $77.8 \%$. The corresponding values of solar irradiance incident on a horizontal plane and wind speed were $320 \mathrm{w} / \mathrm{m}^{2}$ and $0.6 \mathrm{~m} / \mathrm{s}$ respectively. It is clear that a perfect environmental control level in water temperature $\left(T_{w}\right)$ within the fish pond was acheived regardless the ambient environment. The hourly average value throughout the entire experimental period was $26.8^{\circ} \mathrm{C}$ (SD $=0.15)$. Air temperature inside the greenhouse $\left(T_{i a}\right)$ has the same diurnal behavior as the outside ambient air $\left(T_{o a}\right)$. The average value of air temperature rise inside the greenhouse was $8.4{ }^{\circ} \mathrm{C}$. 


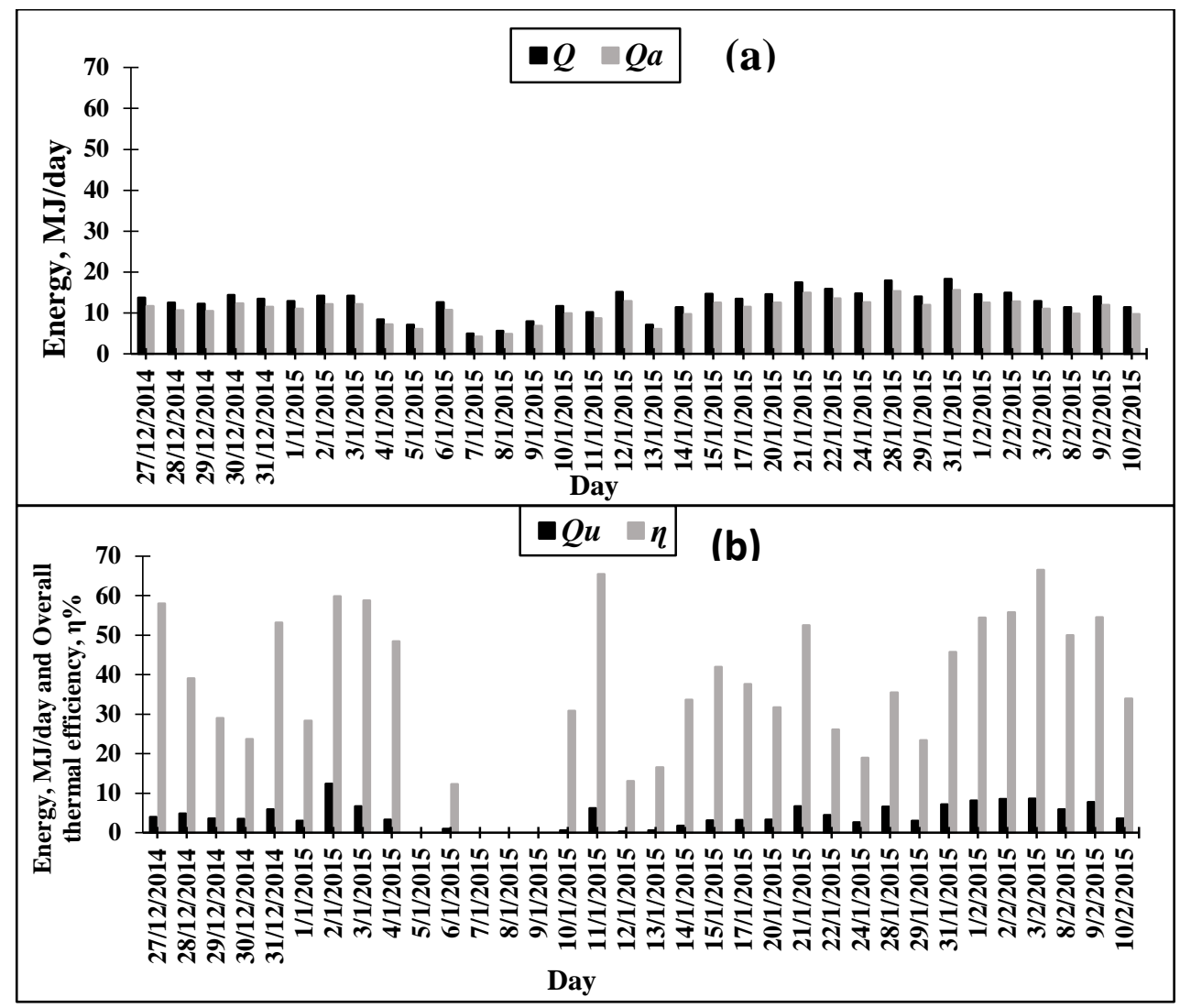

Figure 4: (a) total daily of available solar energy $(Q)$ and absorbed solar energy $\left(Q_{a}\right)$ during the experimental period. (b) Total daily of Useful thermal energy gain to storage $\left(Q_{u}\right)$ and overall thermal efficiency $(\eta)$ during the experimental period

Regarding the greenhouse cover, it was found that the inner one has a heigher temperature $\left(T_{i c}\right)$ than the outer cover throughout the entire day. This is in agreement with $\mathbf{L i}$ et al. (2009) and is due to convection thermal gaing from the inside air to the inner cover and loss from the outer cover to the outside ambient air.

Figure (6) shows the hourly average throughout the entire experimental period of solar irradiance incident on a horizontal plane $\left(I_{h}\right)$ and on the surface of greenhouse sides (Inclined facing south $\left(I_{\text {incl }}\right)$, vertical facing south $\left(I_{S}\right)$, vertical facing east $\left(I_{E}\right)$ vertical facing west $\left(\mathrm{I}_{\mathrm{W}) \text {, and vertical }}\right.$ facing north $\left(I_{N}\right)$ ). 


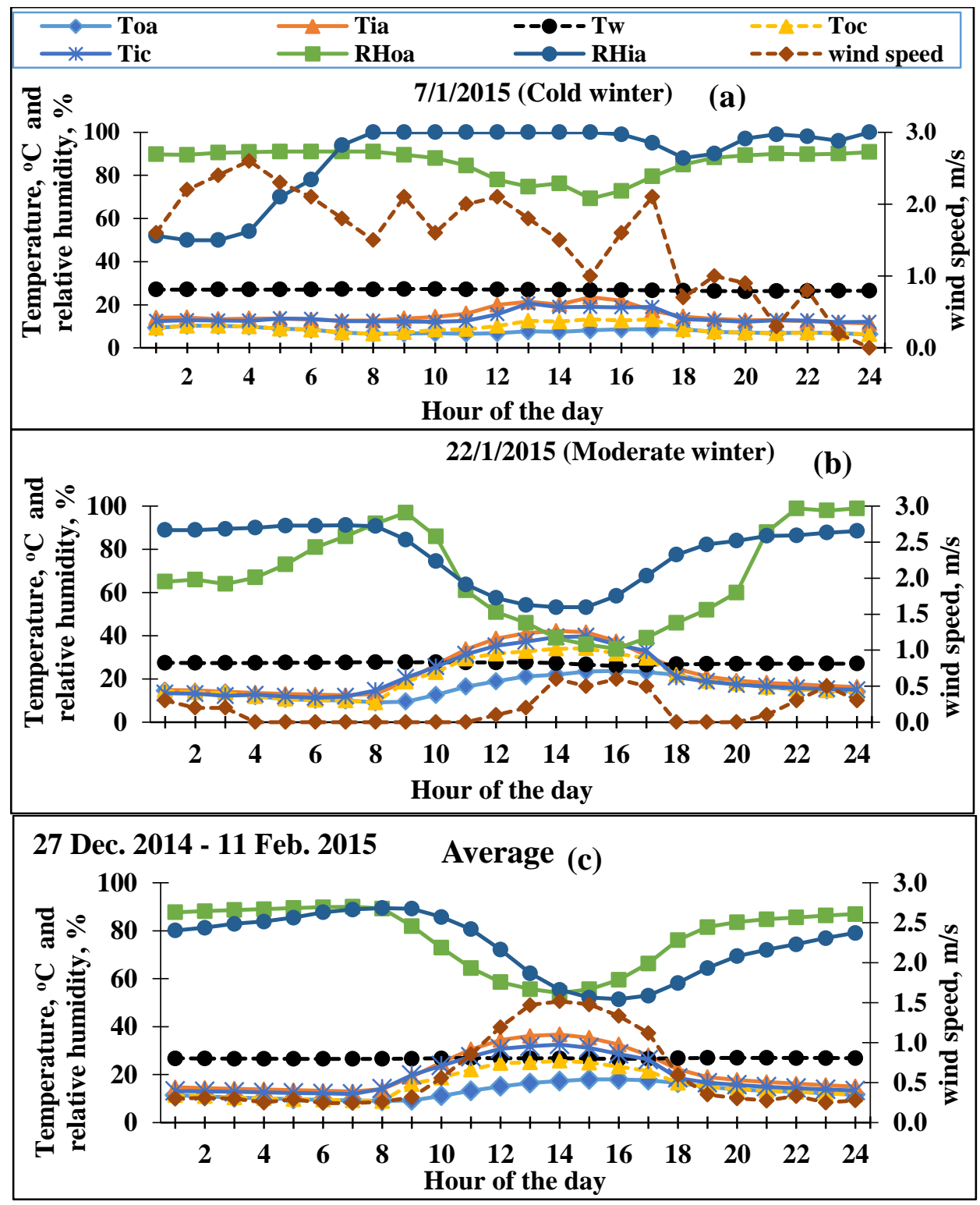

Figure 5: Hourly measured of the outside ambient air temperature $\left(T_{o a}\right)$ and relative humidity $\left(\mathrm{RH}_{o a}\right)$, inside air temperature $\left(T_{i a}\right)$ and relative humidity $\left(\mathrm{RH}_{\mathrm{ia}}\right)$, fish pond water temperature $\left(T_{w}\right)$, outer and inner cover temperatures $\left(T_{o c}\right.$ and $T_{i c}$ respectivly) and wind speed for cold and moderate winter days ((a) and (b)) in addition to the hourly average for the same parameters throughout the entire experimental period (c). 
Maximum values sorted descending for $I_{\text {incl }}, I_{S}, I_{h}, I_{E}, I_{W}$ and $I_{N}$ were 958 $\mathrm{W} / \mathrm{m}^{2}$ at hour $13: 00,730 \mathrm{~W} / \mathrm{m}^{2}$ at hour 13:00, $615 \mathrm{~W} / \mathrm{m}^{2}$ at hour 12:00, $595 \mathrm{~W} / \mathrm{m}^{2}$ at hour10:00, $489 \mathrm{~W} / \mathrm{m}^{2}$ at $16: 00$ and $155 \mathrm{~W} / \mathrm{m}^{2}$ at 12:00, respectively. Generaly, it is evident that the inclined surface receives more solar energy than the others. This in conjunction with that it has the greatst area among them gives it an advantage in the transmitted and accuired energy as shown in Figure 7.

Figure 7 indicates the hourly mean of solar energy transmitted and accuired by greenhouse for all sides ( $Q_{g h N}, Q_{g h i n c l}, Q_{g h S}, Q_{g h W}$ and $\left.Q_{g h E}\right)$ during the experimental period. As mentioned before the largest value was achieved by the inclined surface and reached $15.899 \mathrm{~kW}$ at hour 13:00. The integrated and acumulated solar energy as the total daily average were $373.259,68.476,67.706,61.605$ and $43.406 \mathrm{MJ}$ per day for $Q_{\text {ghincl }}, Q_{g h E}, Q_{g h S}, Q_{g h W}$ and $Q_{g h N}$.

Regarding the fish pond water temperature control level daily average of the outside and inside air temperatures ( $T_{o a}$ and $T_{i a}$ respectively), fish pond water temperature $\left(T_{w}\right)$ and daily thermal load leveling (TLL) throughout the entire experimental period are illustrated in Figure 8. It is evident that although the air temperature outside and inside the greenhouse varied in the range from 7.86 to 17.51 and from 15.21 to $24.76{ }^{\circ} \mathrm{C}$ respectively, water temperature was maintained in the range from 23.93 to $28.28{ }^{\circ} \mathrm{C}$ at an average $\left(26.8{ }^{\circ} \mathrm{C}(\mathrm{SD}=0.15)\right)$ of almost the set point one $\left(27^{\circ} \mathrm{C}\right)$. This pointed to the considerable contribution of the heat exchanger system including the solar collector and the auxialary systems in controlling water temperature. On the other hand the contribution of the greenhouse system in controlling the water temperature is clear in the air temperature rise inside the greenhouse. Daily thermal load leveling (TLL) as another parameter to judge the water temperature control throghout the entire experimental period was shown in Figure 8 as well. It varies from 0.01 to 0.23 at an average of 0.04 . The lower the TLL the lower the temperature fluctuations, i.e. the better the water temperature control. However the high values of TLL arise at days $6,7,32$ and 43 were noticed when the daily average water temperature decreases under the desired level and concequently the need for more heating. As a noticable conclusion could be mentioned here that the water exchange did not have a significant effect on the fish pond water temperature. 


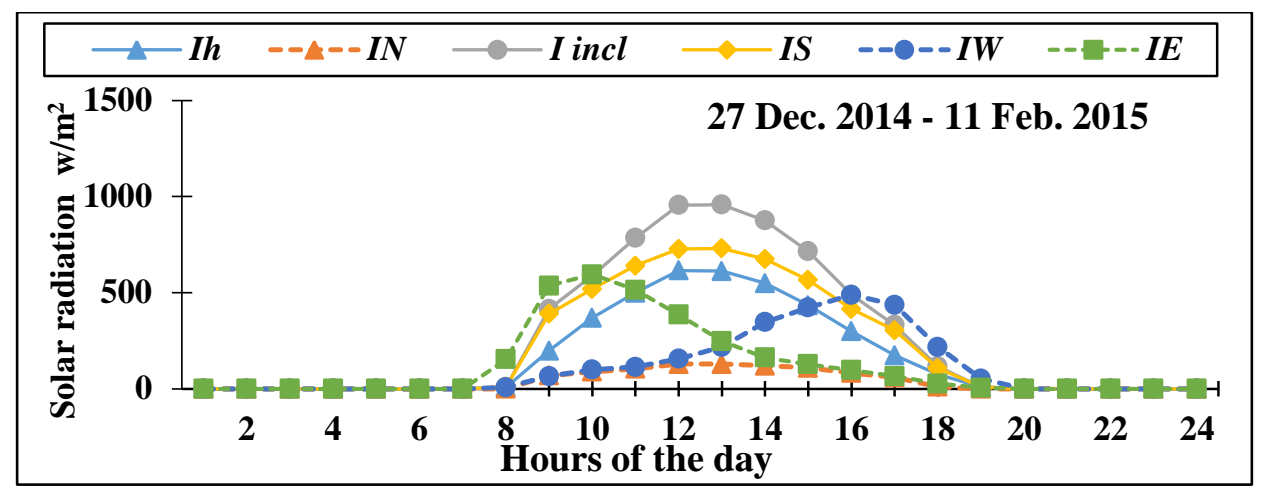

Figure 6: Hourly average throughout the entire experimental period of solar irradiance incident on a horizontal plane $\left(I_{h}\right)$ and on the surface of greenhouse sides (Inclined facing south $\left(I_{\text {incl }}\right)$, vertical facing south $\left(I_{S}\right)$, vertical facing east $\left(I_{E}\right)$ vertical facing west $\left(I_{W}\right)$, and vertical facing north $\left(I_{N}\right)$ ).

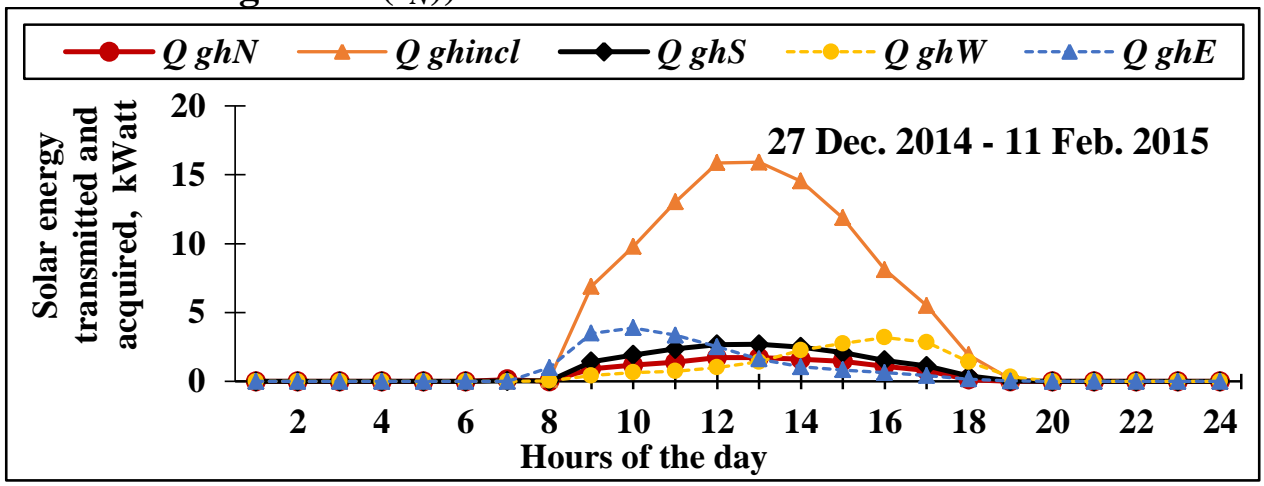

Figure 7: Hourly average of the solar energy transmitted and acquired by greenhouse $\left(Q_{g h}\right)$ for all sides $\left(Q_{g h N}, Q_{g h i n c l}, Q_{g h S}, Q_{g h W}\right.$ and $\left.Q_{g h E}\right)$ during the experimental period.

Total daily values per $\mathrm{m}^{2}$ of fish pond water surface area energy gained from the heat exchanger $\left(Q_{w g}\right)$ was shown in Figure 9 in conjunction with the global solar radiation incident on a horizontal plane $\left(I_{h}\right)$. As it was expected $Q_{w g}$ increases when $I_{h}$ decreases. The average value of total daily of energy gained $\left(Q_{w g}\right)$ was $18.185(\mathrm{SD}=7.46) \mathrm{MJ} /\left(\mathrm{m}^{2}\right.$.day) at a corresponding average of $13.433(\mathrm{SD}=2.92) \mathrm{MJ} /\left(\mathrm{m}^{2}\right.$.day $)$ for the global solar radiation. This means saving a daily average value of $5.051 \mathrm{~kW}$.h of traditional electrical energy per $\mathrm{m}^{2}$ of the fish pond water surface area. 


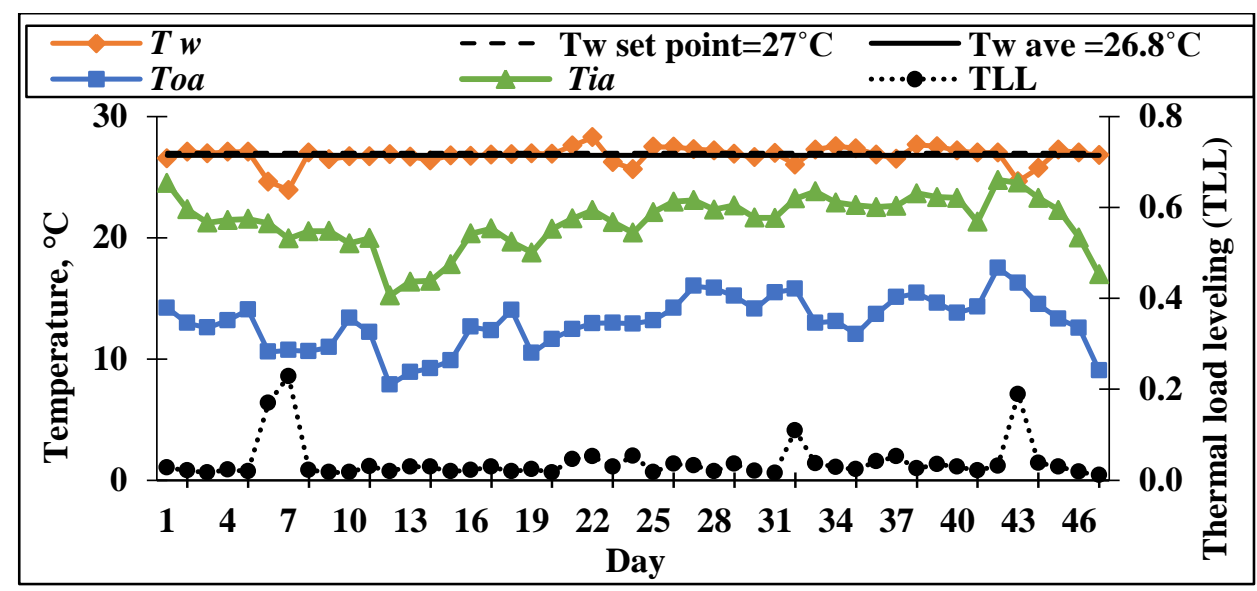

Figure 8: Daily average of the outside and inside air temperatures ( $T_{0 a}$ and $T_{i a}$ respectively), fish pond water temperature $\left(T_{w}\right)$ and daily thermal load leveling (TLL) throughout the entire experimental period.

However by eliminating the electric heater energy consumption based on its operating time and power which was calculated as a daily average of about $2.894 \mathrm{~kW} . \mathrm{h}$ per $\mathrm{m}^{2}$ of the fish pond water surface area the rest which is 2.157 still can be saved. On the other hand the very small $(0.225$ $\mathrm{kW} \cdot \mathrm{h} /\left(\mathrm{m}^{2}\right.$.day $)$ ) electrical energy consummed by the heat exchanger pump was not included. As a conclusion the ambient thermal conditions have an emphasized role in water energy gain.

To distinguish between the impact of both greenhouse and heat exchanger based on their operating times the percentage of energy contribution of both greenhouse action and heat exchanger operating times on a weekly basis are illustrated in Table 5. Greehouse energy conribution was predominant compared to the heat exchanger for all weeks except the second and the third weeks. This exception refers mainly to the abmbient weather conditions since it was noticed that thses two weeks were of the most coldest periods during the present experimental work. As a weekly average the greenhouse energy contribution represents about $58.13 \%$ of the whole operating time and the rest $(41.87 \%)$ was accomplished by the heat exchanger system. It should be emphasized here that the time during which the heat exchanger is in operation the greenhouse impact is limited to keep the internal heat and to reduce the energy loss. 


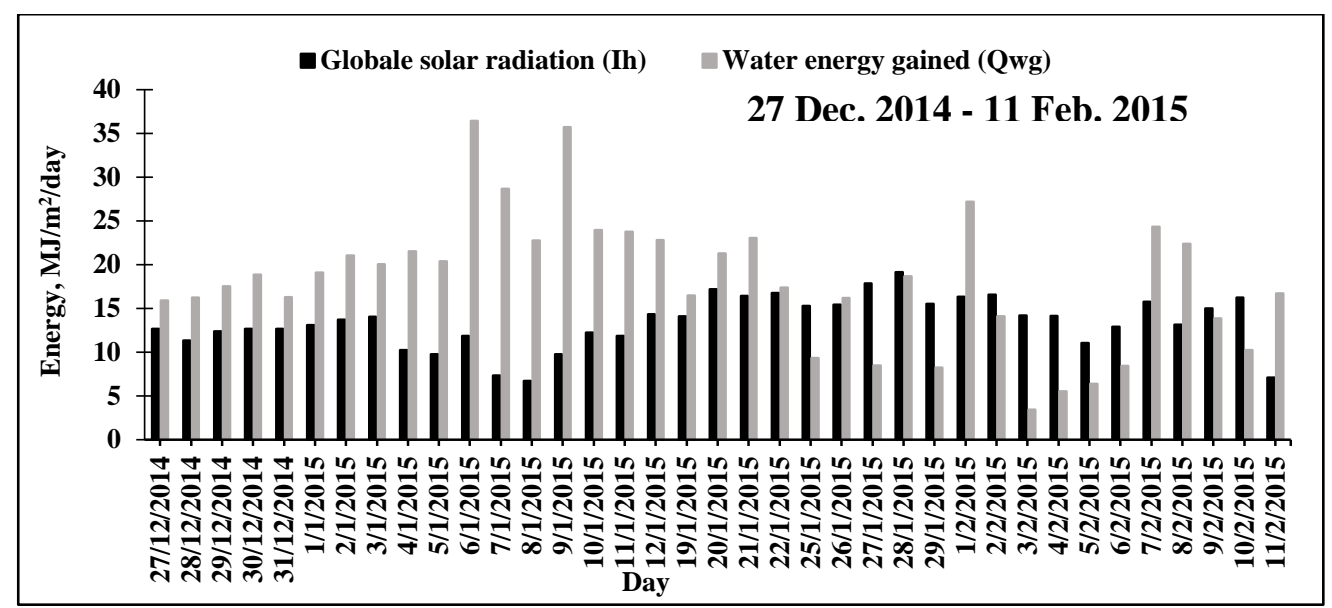

Figure 9: Total daily of global solar radiation $\left(I_{h}\right)$ and Water energy gained from the heat exchanger $\left(Q_{w g}\right)$ per day.

Table 5: Weekly average of the percentage of energy contribution for both heat exchanger and greenhouse action operating times.

\begin{tabular}{|l|c|c|}
\hline & Heat exchanger \% & Greenhouse \% \\
\hline week 1 & 40.65 & 59.35 \\
\hline week 2 & $\mathbf{5 1 . 1 5}$ & $\mathbf{4 8 . 8 5}$ \\
\hline week 3 & $\mathbf{5 4 . 5 6}$ & $\mathbf{4 5 . 4 4}$ \\
\hline Week4 & 49.58 & $\mathbf{5 0 . 4 2}$ \\
\hline Week5 & 29.06 & $\mathbf{7 0 . 9 4}$ \\
\hline Week6 & $\mathbf{2 5 . 6 5}$ & $\mathbf{7 4 . 3 5}$ \\
\hline Week7 & $\mathbf{4 2 . 4 2}$ & $\mathbf{5 7 . 5 8}$ \\
\hline average & $\underline{41.87}$ & $\underline{58.13}$ \\
\hline
\end{tabular}

Regarding water quality, the daily average of dissolved oxygen of the fish pond water during the experimental period is shown in Figure 10. It is obvious that the level of dissolved oxygen did not fall under $5 \mathrm{ppm}$ as a minimum threshold level. However daily average value of $7.62(\mathrm{SD}=$ $0.68) \mathrm{ppm}$ with a minimum value of $6.24 \mathrm{ppm}$ were achieved. However ammonia, $\mathrm{pH}$ and electrical conductivity levels were checked more than one time during the experimental period and were ranged from 0.13 to $0.29 \mathrm{ppm}$, from 8 to 8.5 and from $0.660 \mathrm{dS} / \mathrm{m}$ respectively.

Because of the importance of the photoperiod for fish hatching process Figure 11 shows the hourly average of illumination intensity during the experimental period. A 14 hours lighting period per day were maintained at an average of 19800 and 1650 Lux for daytime (10 hours) and nighttime (4 hours) respectively. 


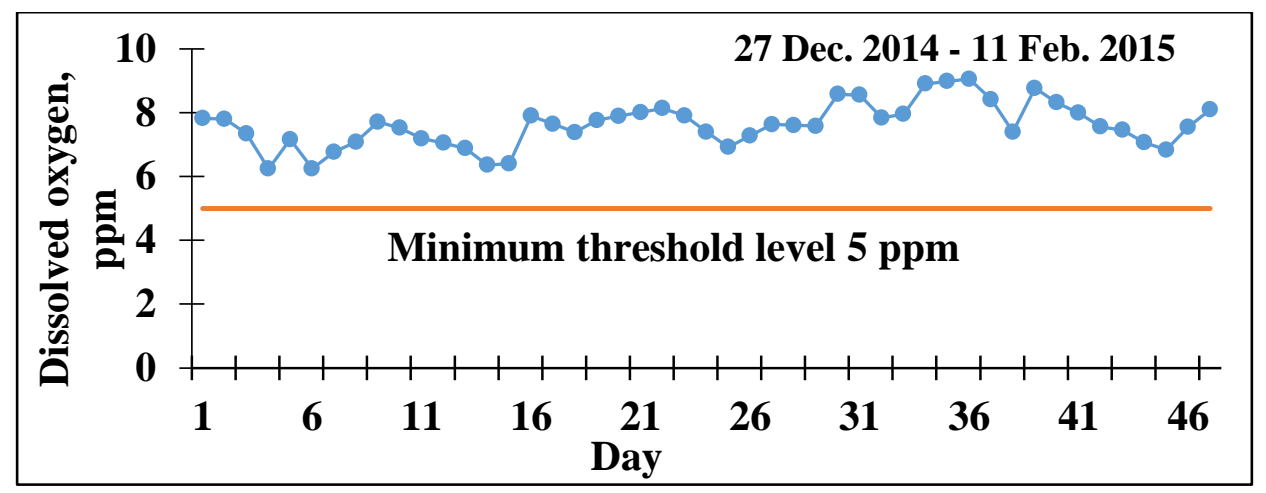

Figure 10: Daily average of dissolved oxygen during the experimental period.

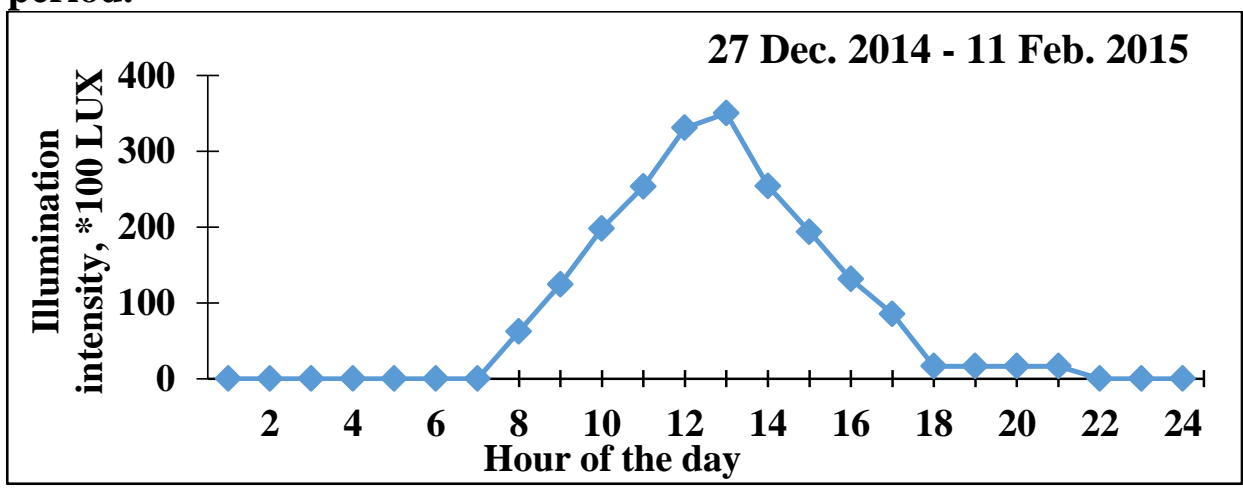

Figure 11: Hourly average of illumination intensity during the experimental period.

\section{Production rate:}

According to Kour et al. (2014) the one female of $100 \mathrm{~g}$ weight can produce an approximate number of 100 eggs per spawn. Therefore and since the female average weight in the present study was $180 \mathrm{~g}$ each female produced approximately 180 eggs. Number of fingerlings was accounted by the end of the experimental period and was found to be 115 . Consequently the hatching ratio of about $63.9 \%$ was achieved. An advantage of the earliest fingerlings production under the suggested thermo-solar greenhouse hatchery was achieved since the fingerlings was ready to be transferred by the end of February. On the other hand the average weight of a single fish of males and females at the end of the experimental period (47 days) were 290 and 200 g respectively. Weight 
increasing percentage were 45 and $11.1 \%$ for males and females respectively.

\section{SUMMARY AND CONCLUSIONS}

Energetic performance of a thermo-solar greenhouse representing a fish hatchery system was suggested, developed and investigated. The developed system was mainly consisted of a double cover greenhouse coupled with a solar collector and heat exchanger for water heating. The main aim was to control the water environment, namely temperature and dissolved oxygen, of a fish (Nile Tilapia) hatchery at the desired levels. The following parameters that can assess the energetic performance of the investigated system can be concluded as follow:-

- Grand mean for outside ambient air temperature and relative humidity, inside air temperature and relative humidity were $13{ }^{\circ} \mathrm{C}$, $74 \%, \quad 21.4{ }^{\circ} \mathrm{C}$ and $77.8 \%$. The corresponding values of solar irradiance incident on a horizontal plane and wind speed were 320 $\mathrm{W} / \mathrm{m}^{2}$ and $0.6 \mathrm{~m} / \mathrm{s}$ respectively. The achieved corresponding value of air temperature rise inside the greenhouse was $8.4^{\circ} \mathrm{C}$.

- The average value of overall thermal efficiency of the solar collector was $40 \%$ at corresponding value of solar irradiance on the solar collector surface and on the horizontal plane and ambient outside air temperature throughout the operating period of solar collector of about, $722 \mathrm{~W} / \mathrm{m}^{2}, 475 \mathrm{~W} / \mathrm{m}^{2}$ and $15.27{ }^{\circ} \mathrm{C}$, respectively.

- The average value of total daily water energy gained from the heat exchanger was $18.185 \mathrm{MJ} /$ day per $\mathrm{m}^{2}$ of water surface area at an average value of $13.433 \mathrm{MJ} /\left(\mathrm{m}^{2}\right.$.day) of the incident solar radiation on the horizontal plane.

- Based on their operating time the weekly average percentage of energy contribution of both greenhouse action and heat exchanger operating times were $58.13 \%$ of the whole operating time and the rest which is $41.87 \%$ was accomplished by the heat exchanger system.

- A paramount temperature control and dissolved oxygen levels of the fish pond water were achieved. The average temperature and dissolved oxygen concentration of water pond throughout the whole 
experimental period were $26.8(\mathrm{SD}=0.15){ }^{\circ} \mathrm{C}$ and $7.62(\mathrm{SD}=0.68)$ ppm respectively.

- The average of fingerlings production rate was 115 eggs / female hatched by almost $63.9 \%$.

\section{REFERENCES}

Abou-Zied, R.M. and A. A. Ali (2007). Evaluation of Nile tilapia commercial hatcheries system in Fayoum governorate. Egypt. J. Aquat. Biol. Fish. 11 (3), 230-238.

Duffie J. A. and W. A. Beckman (2013). Solar Engineering of Thermal Processes, John Wiley \& Sons, Inc. New York. Fourth Edition.

Eldokla, A. A.; G. E. Azazy and W. A. E. Elabd (2011). Economic study for themain factor affecting tilapia propagation activities. J. Agric. Env. Sci., vol. 10. Damanhur University, pp. 1-13.

El-Husseiny, O. M.; A. M. Goda; G. M. Abdul-Aziz and E. R. ElHaroun (2007). Fish meal free diets for Nile Tilapia Oreochromis niloticus (L.). Mugill cephalous and liza Ramada in Semi-intensive polyculture system in earthen ponds. Egyptian J. Nutrition and Feeds 10 (1): 179-203.

El-Saidy, D. M. S. and M. M. A. Gaber (2005). Effect of dietary protein levels and feeding rates on growth performance, production trains and body composition of Nile tilapia, Oreochromis niloticus cultured in concrete tanks. Aquaculture Research, 36 (2): 163-171.

FAO (2013). The Global Aquaculture Production Statistics for the year 2011. Fisheries and Aquaculture Department.

Fuller, R. J. (2007). Solar heating systems for recirculation aquaculture. Aquacultural Engineering 36, 250-260.

GAFRD (General Authority for Fishery Resources Development), (2011). Statistics of Fish Production. Ministry of Agriculture and Land Reclamation. Eygpt.

Jain, D. and G. N. Tiwari (2003). Modeling and optimal design of ground air collector for heating in controlled environment greenhouse. Energy Conversion and Management; 44:1357-72.

Kour R.; S. Bhatia and K. K Sharma (2014). Nile Tilapia (Oreochromis niloticus) as a successful biological invader in Jammu $(\mathrm{J} \& \mathrm{~K})$ and its impacts on native ecosystem. International Journal of 
Interdisciplinary and Multidisciplinary Studies (IJIMS). Vol (1) No.10, 1-5.

Li, D. S.; D. H. Willits; C. L. Browdy; M. B. Timmons; and T. M. Losordo (2009). Thermal modeling of greenhouse aquaculture raceway systems. Aquacultural Engineering, (41):1-13.

Little, D. C. and G. Hulata (2000). Strategies for tilapia seed production. In: Beveridge, M. C. M., McAndrew, B. J. (Eds.), Tilapias: biology and exploitation. Fish and Fisheries Series, 25. Kluwer Academic Publishers, Dordrecht, The Netherlands, pp. 267 326.

Macfadyen, G.; A. M. Nasr Allah; D. A. R. Kenawy; F. Mohamed; H. Hebicha; A. Diab; S. M. Hussein; R. Abouzied and G. EI Naggar (2012). Value-chain analysis - an assessment methodology to estimate Egyptian aquaculture sector performance, and to identify critical issues and actions for improvements in sector performance. Aquaculture. 362-363, 18-27.

Mwegoha, W. J. S.; M. E. Kaseva and S. M. M. Sabai (2010). Mathematical modeling of dissolved oxygen in fish ponds. African Journal of Environmental Science and Technology, 4 (9): 625-638. http://www.academicjournals.org/ AJEST.

Naiel, R. A. ; M. G. Aamer; A. A. Ibrahim and G. E. Azazy (2011). Economics of fry production of fish hatcheries. Zagazig J. Agric. Res. 38 (5), 1329-1341.

Nasr-Allah, A. M.; M. Dickson; D. A. Al-Kenawy; M. F. Mohamed and G. El Naggar (2012). Value chain analysis of Egyptian fish seed production. Study Report World Fish Center.

Radwan, I. (2008). Tilapia aquaculture in the Nile Delta 1990-2008. In: Elghobashy, H., Fitzsimmons, K., Diab, A.S. (Eds.), Proceedings of $8^{\text {th }}$ International Symposium on Tilapia in Aquaculture, Cairo, Egypt, 12-14 Oct 2008, pp. 605-611.

Sadek, S. (2011). An overview on desert aquaculture in Egypt. In: Crespi, V., Lovatelli, A. (Eds.), Aquaculture in desert and arid lands: development constraints and opportunities. FAO technical workshop. 6-9 July 2010, Hermosillo, Mexico. FAO Fisheries and Aquaculture Proceedings No. 20. FAO, Rome, pp. 141-158. 
Saleh, M. A. (2007). Freshwater fish seed resources in Egypt. In: Bondad-Reantaso, M.G. (Ed.), Assessment of Freshwater Fish Seed Resources for Sustainable Aquaculture, FAO Fisheries Technical Paper. FAO, Rome, pp. 241-255.

Shaheen, A. A. (2013). An industry assessment of tilapia farming in Egypt. African Union - Inter-African Bureau for Animal Resources. pp 25, 13, 12.

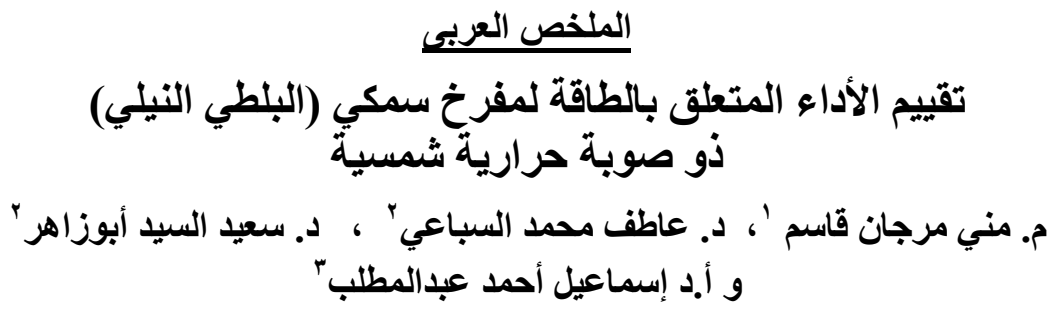

تعتبر عملية التفريخ السمكي لانتاج الزريعه من العمليات التي تعتمد بشكل كبير علي الطاقة، ومن ثم البحث عن تقنيات منطورة وجديدة ومبتكرة لتقليل الاعتماد علي الطاقة التقليدية و الانتقال

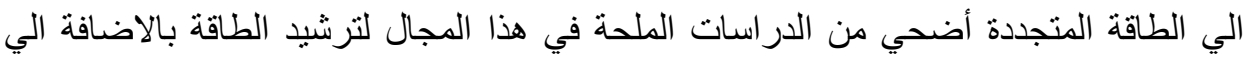

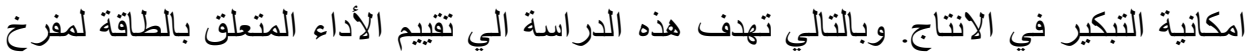

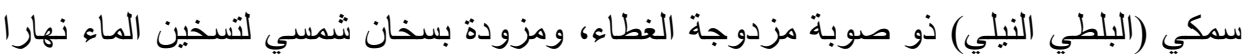

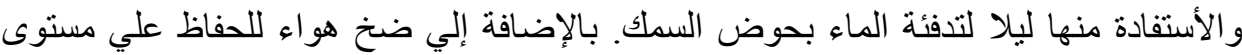

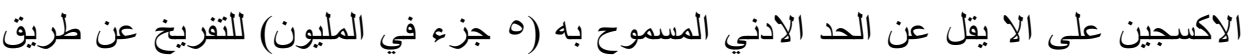

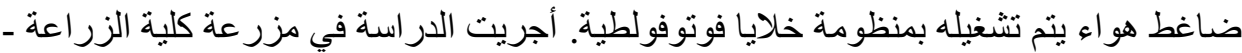

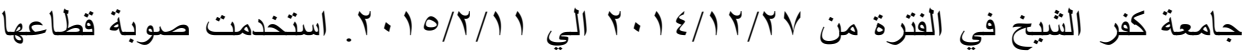

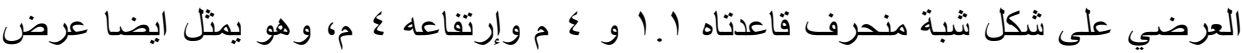

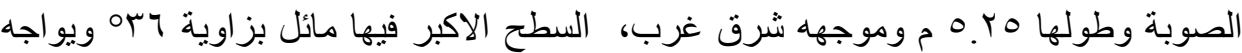

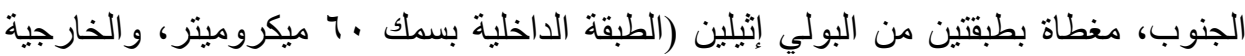

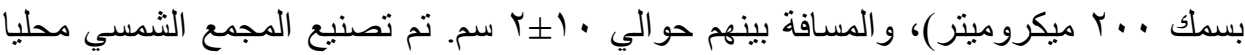

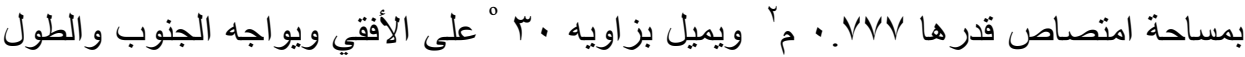

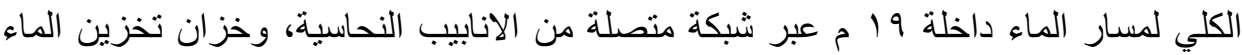

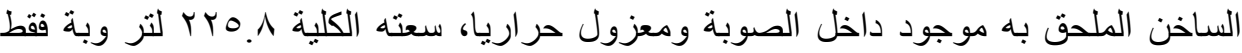

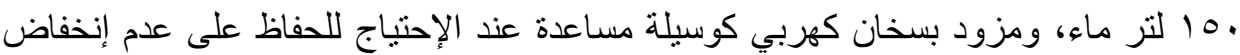

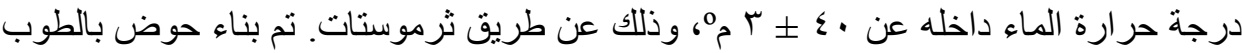

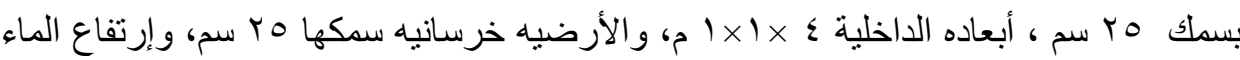

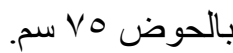

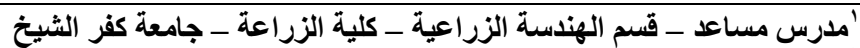

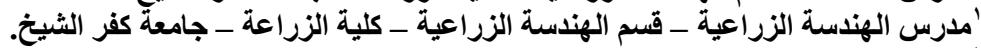
'أستاذ الهندسة الزراعية المتفرغ ـ قسم الهندسة الزراعية ـ ـلية الزراعة الزعة ـ جامعة كفر الثيخ. 
إستخدمت ماسورة نحاس في أرضية الحوض علي شكل حرف Uمبادل حراري في عملية

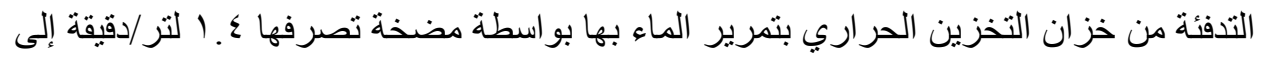
الحوض. كما تم وضع ثرموستات اخر أيضا بحوض السمك للتحكم في تشغيل و إيقاف مضخه

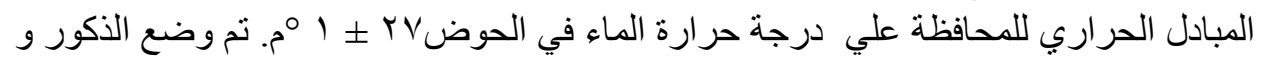

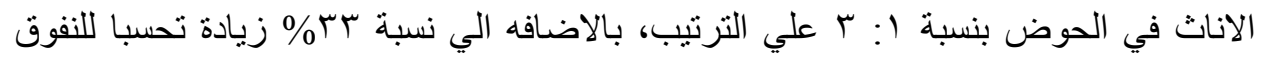

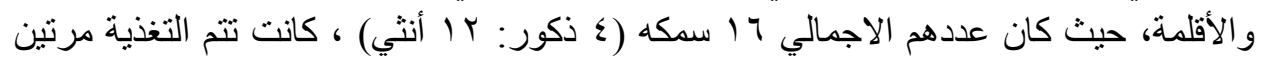

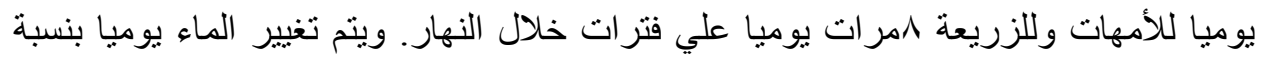

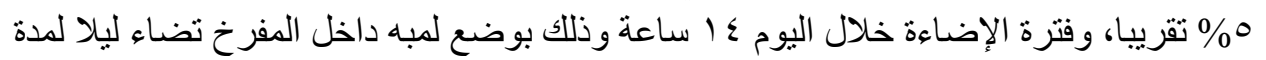

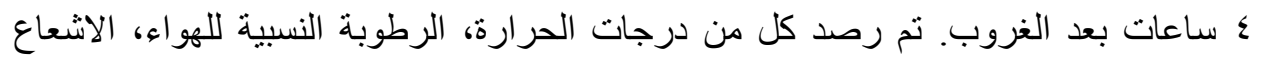

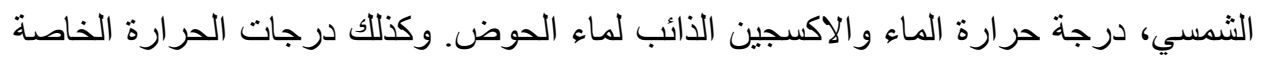
بالمجمع الثمسي و المبادل الحراري، أزمنة التشخيل لكل من مضخة المبادل الحراءي واري و السخان

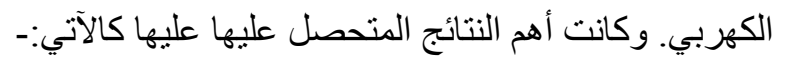

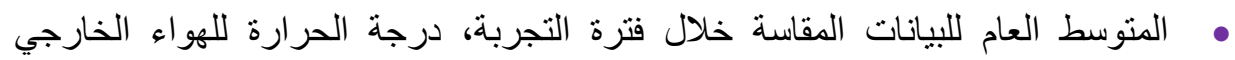

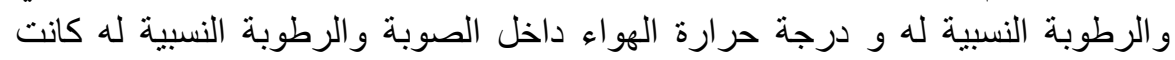

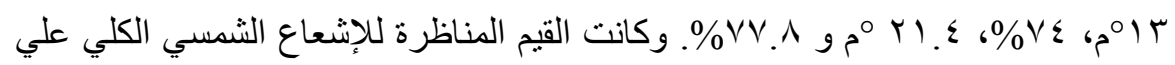

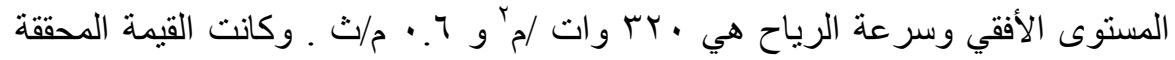

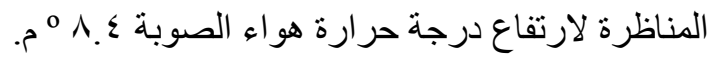

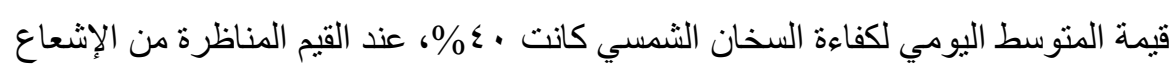

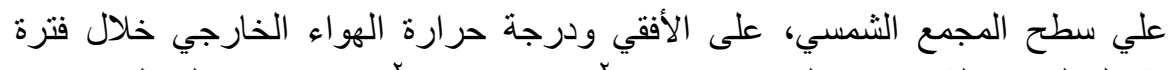

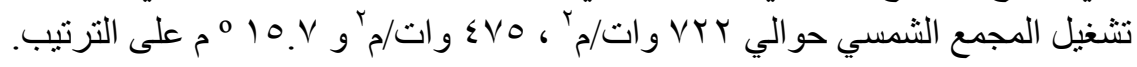

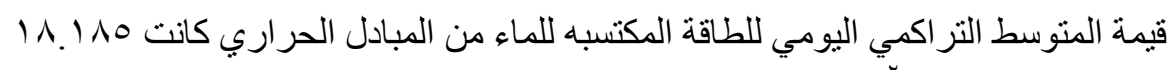

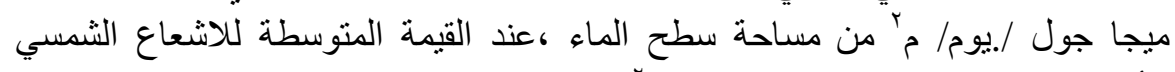

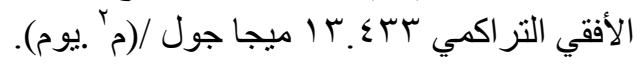
إعتمادا علي زمن تشغيل المبادل الحراري فقد ساهمت الصوبة الصابة بقيمة متوسطه إسبو عية

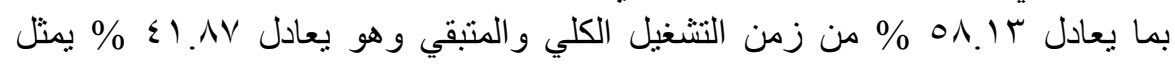

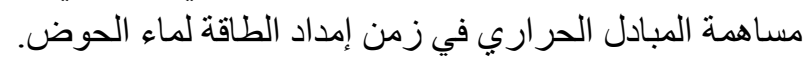
تم تحقيق مستوى مرتفع من التحكم في كلا من درجة الحرارة والاكسجين الذائب لماء

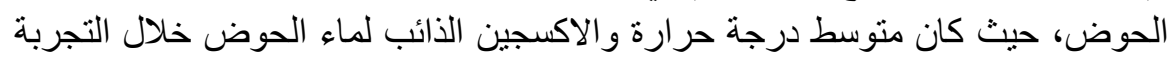

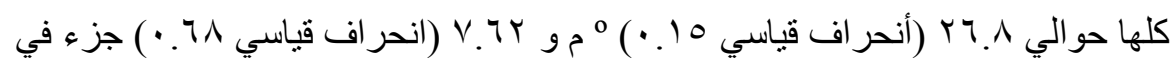
المليون علي الترنيب. متوسط معدل الانتاج من الزريعه حو الي 11 ا بيضة / انتي بنسبة فقس 9, 9 \%٪. 